Review

\title{
Environmental Conditions and Agronomical Factors Influencing the Levels of Phytochemicals in Brassica Vegetables Responsible for Nutritional and Sensorial Properties
}

\author{
Francesca Biondi ${ }^{1,2}{ }^{2}$ Francesca Balducci ${ }^{1}$, Franco Capocasa ${ }^{1}$ (D), Marino Visciglio ${ }^{2}$, Elena Mei ${ }^{2}$, \\ Massimo Vagnoni ${ }^{2}$, Bruno Mezzetti ${ }^{1}$ (D) and Luca Mazzoni ${ }^{1, *}$ \\ 1 Department of Agricultural, Food and Environmental Sciences, Università Politecnica delle Marche, \\ via Brecce Bianche 10, 60131 Ancona, Italy; fra90ap@hotmail.it (F.B.); francesca.balducci@staff.univpm.it (F.B.); \\ f.capocasa@staff.univpm.it (F.C.); b.mezzetti@staff.univpm.it (B.M.) \\ 2 Valli di Marca ss Agricultural Company, c/da Valle 2, 63068 Montalto delle Marche, Italy; \\ marino.visciglio@gmail.com (M.V.); maddymei@hotmail.it (E.M.); massimo.agv@gmail.com (M.V.) \\ * Correspondence: 1.mazzoni@staff.univpm.it; Tel.: +39-071-220-4640
}

check for updates

Citation: Biondi, F.; Balducci, F.; Capocasa, F.; Visciglio, M.; Mei, E.; Vagnoni, M.; Mezzetti, B.; Mazzoni, L. Environmental Conditions and Agronomical Factors Influencing the Levels of Phytochemicals in Brassica Vegetables Responsible for

Nutritional and Sensorial Properties. Appl. Sci. 2021, 11, 1927. https:// doi.org/10.3390/app11041927

Academic Editors:

Alessandro Genovese and Carmela Spagnuolo

Received: 14 December 2020

Accepted: 19 February 2021

Published: 22 February 2021

Publisher's Note: MDPI stays neutral with regard to jurisdictional claims in published maps and institutional affiliations.

Copyright: (c) 2021 by the authors. Licensee MDPI, Basel, Switzerland. This article is an open access article distributed under the terms and conditions of the Creative Commons Attribution (CC BY) license (https:/ / creativecommons.org/licenses/by/ $4.0 /)$.

\begin{abstract}
Recently, the consumption of healthy foods has been related to the prevention of cardiovascular, degenerative diseases and different forms of cancers, underlying the importance of the diet for the consumer's health. Fruits and vegetables contain phytochemicals that act as protective factors for the human body, through different mechanisms of action. Among vegetables, Brassica received a lot of attention in the last years for the phytochemical compounds content and antioxidant capacity that confer nutraceutical value to the product. The amount of healthy bioactive compounds present in the Brassica defines the nutritional quality. These molecules could belong to the class of antioxidant compounds (e.g., phenols, vitamin C, etc.), or to non-antioxidant compounds (e.g., minerals, glucosinolates, etc.). The amount of these compounds in Brassica vegetables could be influenced by several factors, depending on the genotypes, the environmental conditions and the cultivation techniques adopted. The aim of this study is to highlight the main phytochemical compounds present in brassicas used as a food vegetable that confer nutritional and sensorial quality to the final product, and to investigate the main factors that affect the phytochemical concentration and the overall quality of Brassica vegetables.
\end{abstract}

Keywords: phytochemical compounds; antioxidant capacity; Brassica spp.; vegetables; cultivation techniques; glucosinolates

\section{Introduction}

In recent years, the increasing incidence of cardiovascular, degenerative diseases and different forms of cancers has stimulated the interest of consumers in distinguishing healthy from unhealthy foods, as a consequence of the abandonment of Mediterranean diet which, in contrast to other eating regimes, was considered a model of healthy eating for years. The interest for consuming healthy food led to coining the new definition "functional food" for several foodstuffs. This term defines a food product that, in addition to carrying out the traditional alimentary function, also performs preventive and/or therapeutic effects against various human diseases, in particular chronic-degenerative diseases [1,2]. Fruits and vegetables contain phytochemicals that are responsible for these positive effects on human body.

Among vegetables, brassicas received a lot of attention in the last few years. They comprise a large and diverse group of widely consumed vegetables. Brassica is the Latin name of a genus that is taxonomically placed within the Brassicaceae (Cruciferae). The main cultivated and most consumed as food vegetables Brassica species in the world are indicated in Table 1. Other closely related vegetables within the Brassicaceae family are also reported. 
The healthy potential of Brassica is bound to their phytochemical compounds. The main compounds responsible for healthy function are phenolic compounds, vitamins $(C, B 9, K)$, provitamin A ( $\beta$-carotene), lutein and different types of glucosinolates [3]. The increasing interest for Brassica vegetables has been underlined by their economic importance (among the top 10 economic crops in the world [4]) and by the fact that there was an increase of about $11.5 \%$ of both the cultivated area and the production quantity from 2009 to 2019, with a slight increase in yield of about $1.5 \%$. The Organization for Food and Agriculture of the United Nations (FAO) also reported that, in 2019, the global production of cauliflower, broccoli, cabbage and other Brassica crops was about 97 million tonnes, occupying a cultivated area of almost 4 million hectares. Asia accounts for more than $75 \%$ of the global Brassica vegetable production, with China producing almost a half of all of these vegetables (45 million tonnes). India, with more than 18 million tonnes, then Korea, Russia, and USA with more than 2 million tonnes, are also the biggest producers of cauliflower, broccoli, cabbage and other Brassica crops [5].

Table 1. Main species, subspecies (ssp.) and varieties (var.) of Brassicaceae family crops consumed as food vegetable in the world [4,6-8].

\begin{tabular}{|c|c|c|}
\hline Species & ssp./var. & Common Name/Italian Name \\
\hline \multirow[t]{9}{*}{ Brassica oleracea L. } & italica & Broccoli \\
\hline & $\begin{array}{l}\text { capitata } \\
\text { capitata f. rubra } \\
\text { capitata f. alba }\end{array}$ & $\begin{array}{c}\text { Cabbage } \\
\text { Red cabbage } \\
\text { White cabbage }\end{array}$ \\
\hline & botrytis & Cauliflower \\
\hline & $\begin{array}{c}\text { acephala sabellica } \\
\text { acephala laciniata } \\
\text { acephala }\end{array}$ & $\begin{array}{c}\text { Curly Kale, Red, Green and Russian curly kale } \\
\text { Black Cabbage, Italian or Tuscan cabbage } \\
\text { Collards }\end{array}$ \\
\hline & gemmifera & Brussels sprouts \\
\hline & gongylodes & Kohlrabi \\
\hline & sabauda & Savoy cabbage \\
\hline & alboglabra & Chinese kale \\
\hline & costata & Tronchuda cabbage \\
\hline \multirow[t]{7}{*}{ Brassica rapa $\mathrm{L}$. } & rapa & Turnip broccoli \\
\hline & sylvestris & Turnip top, broccoli raab/cima di rapa, friarielli \\
\hline & peckinensis & Chinese cabbage \\
\hline & chinensis & Pak-choi, Chinese mustard \\
\hline & japonica & Mizuna, curled mustard, Japanese greens \\
\hline & perviridis & Tendergreen, Spinach mustard \\
\hline & rapifera & Turnip \\
\hline \multirow{2}{*}{ Brassica napus L. } & napus & Rapeseed \\
\hline & napobrassica & Swede/rutabaga \\
\hline $\begin{array}{l}\text { Brassica kaber/Brassica } \\
\text { arvensis/Sinapis arvensis }\end{array}$ & & Charlock/kaber \\
\hline $\begin{array}{c}\text { Brassica alba/Sinapis alba, } \\
\text { Brassica hirta }\end{array}$ & & White or yellow mustard \\
\hline Brassica nigra/Sinapis nigra & & Black mustard \\
\hline Brassica campestris & & Field mustard \\
\hline
\end{tabular}


Table 1. Cont

\begin{tabular}{|c|c|c|}
\hline Species & ssp./var. & Common Name/Italian Name \\
\hline Brassica carinata & & Ethiopian mustard, Abyssinian mustard, Texsel greens \\
\hline Brassica juncea & & Brown mustards \\
\hline Raphanus sativus L. & & Radish \\
\hline Raphanus raphanistrum $\mathrm{L}$. & & Wild radish \\
\hline Nasturtium officinale R. BR. & & Watercress/Crescione d'acqua \\
\hline Eruca sativa Mill. & & Rocket/Rucola \\
\hline Eruca vesicaria $\mathrm{L}$. & & Rocket Ruca, ruchetta \\
\hline Diplotaxis tenuifolia $\mathbf{L}$. & & Wild rocket/Rughetta selvatica \\
\hline Diplotaxis muralis L. & & Wall rocket \\
\hline
\end{tabular}

The present review summarizes the main chemical compounds responsible for the sensorial and nutritional quality of Brassica spp., with particular emphasis on the factors affecting their level.

\section{Nutritional Quality}

Nutritional quality could be defined as the value of the product for the consumer's physical, psychological, or emotional well-being. The first term of this extended definition concerns the effects of food determined by its phytochemicals, i.e., the sum of all beneficial and harmful compounds and their nutritional (or biological) aspects [9]. In the case of Brassica spp., these molecules could belong to the class of antioxidant compounds (e.g., phenols, vitamin C, etc.), exerting their health effects through the ability to scavenge free radicals, or to non-antioxidant compounds (e.g., minerals, glucosinolates, etc.) that exert their function through direct mechanisms in the human metabolism, different from the scavenger activity.

\subsection{Antioxidant Compounds}

Total antioxidant capacity (TAC) is the ability of food to preserve an oxidizable substrate, inactivate the radical species or reduce an oxidized antioxidant. TAC is considered a fundamental parameter for the description of fruits and vegetables nutritional quality; it is an indicator of the presence of bioactive substances belonging to the antioxidants group. Each antioxidant compound performs its protecting activity through different mechanisms and with different efficiency, depending on its chemical structure and the matrix it acts on. For this reason, TAC analysis is usually preferred to the measurement of the single concentration of each antioxidant, mainly if the objective of the study is a general screening of the health effects of different fruit and vegetables.

Brassica vegetables, i.e., broccoli and kale, showed higher antioxidant potential than other vegetable crops, such as spinach, carrots, potatoes, beans and onions. In general, among Brassica vegetables, Brussels sprouts, broccoli, and red cabbage belong to the group that has the highest antioxidant capacity. Common cabbage possesses the lowest antioxidant capacity $[10,11]$. Contrasting results were reported in cauliflower by Azuma et al. [12] and Wu et al. [13]. The analysis of TAC is influenced by the extraction method and the type of reactive species in the reaction mixture [12].

Many researchers studied and identified the main antioxidant molecules present in Brassicaceae [13-16]. These antioxidant compounds belong to two main groups: watersoluble antioxidants and lipo-soluble antioxidants [14,15]. Kurlich et al. [16] and Wu et al. [13] reported that hydrophilic antioxidants are responsible for $80-95 \%$ of TAC in Brassicaceae, while lipo-soluble antioxidants account for only $5-20 \%$. 


\subsubsection{Water-Soluble Antioxidants}

\section{- $\quad$ Phenolic compounds}

Phenolic compounds are the most widespread antioxidant family present in vegetables. This large group of compounds is particularly present in Brassica vegetables and constitutes the main source of antioxidants in these plants [14,17]. These plants produce them as secondary metabolites for protection from pest and insect attack.

Their importance in human health is related to antioxidant and anti-inflammatory properties that could have preventive and/or therapeutic effects against obesity, cancer, and neurodegenerative and cardiovascular diseases [18]. Among Brassica species, kale and broccoli have the highest quantity of total polyphenols with about $13 \mathrm{mg}$ gallic acid/g of dry weight $[19,20]$.

Flavonoids represent common phenolic compounds in Brassica; they possess a lot of biological properties, e.g., antioxidant activity, a capillary protective effect, and an inhibitory effect elicited in various stages of tumours $[14,21]$. They are characterized by numerous subclasses, but the most important in Brassica are the following:

1. Flavonols: together with anthocyanins, they are the main represented flavonoids in Brassica species; they can be found in internal and external parts of leaves, seeds, shoots and sprouts leaves [22,23]. The most represented flavonols in Brassica vegetables are quercetin (up to $23 \mathrm{mg} / 100 \mathrm{~g}$ fresh product in kale), kaempferol (up to $47 \mathrm{mg} / 100 \mathrm{~g}$ fresh product in kale) and isorhamnetin (up to $24 \mathrm{mg} / 100 \mathrm{~g}$ fresh product in kale) [24]. Quercetin, found mainly in kale, is characterized by a strong antioxidant power (higher than vitamin C); it exerts its activity against free oxygen radicals and acts on the prevention of cardiovascular diseases and cancer, atherosclerosis and chronic inflammation, and the induction of enzymes that detoxify carcinogens $[25,26]$. Kaempferol 3-O-sophoroside is the main represented flavonol in broccoli florets; its high intake is linked with a lower risk of coronary heart disease [27]. Kaempferol and quercetin, and in less amounts, myricetin, are the main represented flavonols in B. rapa subsp. sylvestris.

2. Flavones: Apigenin and luteolin are the only flavones detected in hydrolysed extracts of different Brassica vegetables (up to 45 and $12 \mu \mathrm{g} / \mathrm{g}$ of fresh weight in Chinese cabbage, respectively), excluding broccoli, where they were not detected [28].

3. Anthocyanins were detected in Brassica vegetables and described by several authors $[13,29]$. They are present only in bright coloured species and varieties with red, orange and purple pigmentation, such as some kales, purple broccoli, and red and black cabbage. These compounds show an interesting antioxidant activity. The $80 \%$ of anthocyanins present in Brassica species are in the acylated form, more stable and easily absorbable by the organism. The main represented anthocyanins in cruciferous are cyanidin derivatives. In particular, red cabbage possesses eight main types of anthocyanins (for a total of up to $190 \mathrm{mg}$ Cyanidin-3-Glucoside equivalents $/ 100 \mathrm{~g}$ of fresh weight) [30]; cyanidin-3-diglucoside is the most represented [31]. In broccoli, more than 17 anthocyanins were detected [29].

Among phenolic compounds, even if they are not hydro-soluble, it is worth mentioning the lignans, diphenolic compounds that possess several biological activities, through their antioxidant and oestrogenic properties. Lignans may reduce the risk of certain cancers and cardiovascular diseases [16]. Some studies reported that lignans are mainly present in the kale family, broccoli and Brussel sprouts with lariciresinol (972, 599 and $493 \mu \mathrm{g} / 100 \mathrm{~g}$ fresh edible weight of Broccoli, Curly kale and Brussel sprouts, respectively) and pinoresinol $(315,1691$ and $220 \mu \mathrm{g} / 100 \mathrm{~g}$ fresh edible weight of Broccoli, Curly kale and Brussel sprouts, respectively) being the most abundant [15,32].

- Vitamin C and vitamin B9 (Folic Acid)

Vitamin C, or ascorbic acid, is a powerful antioxidant, widely present and studied in fruits; however, many recent works have been focused on the importance of vitamin $C$ in vegetables, mostly in Brassicaceae family. In Brassica vegetables vitamin C concentration 
varies a lot among species and subspecies, and it is strictly genotype- and environmentdependent $[33,34]$. Vitamin C performs countless biological activities in the human body and represents a nutritional compound fundamental for health. Ascorbic acid is a radical scavenger, an enzyme cofactor and a donator/acceptor in electrons transport at the plasma membrane level; its role is fundamental in the regeneration of $\alpha$-tocopherol, and in the prevention and treatment of malignant and degenerative diseases [33,35].

Among Brassica genotypes, Brussel sprouts (76-192 mg/100 g edible portion) and kale (92-186 mg/100 g edible portion) seem to possess the highest content of vitamin C, followed by broccoli (34-146 mg/100 g edible portion) and cauliflower (17-81 mg/100 g edible portion), while white cabbage (19-47 mg/100 g edible portion) possesses the lowest amount [14].

Vitamin B9 (Folic acid) is an important vitamin present in Brassica, mainly in raw broccoli $(63 \mu \mathrm{g} / 100 \mathrm{~g}$ of edible portion), Brussel sprouts ( $61 \mu \mathrm{g} / 100 \mathrm{~g}$ of edible portion) and kale $(141 \mu \mathrm{g} / 100 \mathrm{~g}$ of edible portion) [36], that act as a coenzyme in many single carbon transfer reactions, in the synthesis of DNA and RNA and of protein components. Furthermore, it reduces the level of homocysteine in the blood, a risk factor for cardiovascular diseases. Among the several health activities that folic acid performs, it is strongly important in the prevention of megaloblastic anaemia, neuropsychiatric disorders and various forms of cancer in the foetus during pregnancy, also reducing the risk of neural tube defects [33,37]. These beneficial effects of folic acid, in particular on the pathogenesis of cancer, and neurological, haematological, and cardiovascular diseases may, in part, be due to its antioxidant activity, via its electron-accepting capacity [38,39].

\subsubsection{Lipo-Soluble Antioxidants}

Despite the low incidence of lipo-soluble antioxidants on the TAC of Brassica, several studies confirm the high content of lipo-soluble antioxidant in kale and broccoli, moderate in Brussels sprouts, and low amount in cauliflower and cabbage [33]. Among lipo-soluble antioxidants, carotenoids and vitamin $\mathrm{E}$ are the most important found in Brassica vegetables.

- Carotenoids

Carotenoids are responsible for the orange, yellow and red pigmentation of several fruits and vegetables, mainly carotenes and xanthophylls. The most represented carotenoids in Brassica vegetables are $\beta$-carotene, which the organism transforms to vitamin $A$, and lutein and zeaxanthin [14]. $\beta$-carotene prevents the insurgence of cancer and cardiovascular diseases, and decreases the risk of myocardial infarction, of immune dysfunction and age-related macular degeneration among smokers [33,40]. Muller [41] analysed the total carotenoid content of several Brassica species and reported them in decreasing order: Brussel sprouts $(6.1 \mathrm{mg} / 100 \mathrm{~g})$, broccoli $(1.6 \mathrm{mg} / 100 \mathrm{~g})$, red cabbage $(0.43 \mathrm{mg} / 100 \mathrm{~g})$ and finally white cabbage $(0.26 \mathrm{mg} / 100 \mathrm{~g})$. In the Brassica oleracea genus, kale possesses the highest content of carotenoids with over $10 \mathrm{mg} / 100 \mathrm{~g}$ of the edible portion [41].

The Brassica vegetable with the highest content of lutein and zeaxanthin is kale (3.04$39.55 \mathrm{mg} / 100 \mathrm{~g}$ ); interesting contents were also found in broccoli and Brussels sprouts [14]. In B. rapa species, 16 carotenoids were identified by Wills and Rangga [42]; in B. chinensis, parachinensis and pekinensis, lutein and $\beta$-carotene are the most abundant carotenoids [15].

- Vitamin E

Vitamin $\mathrm{E}$ is formed by groups of compounds known as tocopherols and tocotrienols; in detail, $\alpha$-tocopherol is the main compound found in Brassica vegetables, with the exception of cauliflower, that contains mainly $\gamma$-tocopherol [14,43]. Vitamin E performs a protective activity against coronary heart disease through the inhibition of LDL oxidation [44]. A high intake of vitamin E helps in the prevention of cancers, cardiovascular diseases, neurological disorders, and inflammatory diseases [33]. The content of vitamin $\mathrm{E}$ in Brassica species has been studied in the literature, as reported here in decreasing order: broccoli $(0.82 \mathrm{mg} / 100 \mathrm{~g})$, Brussels sprouts $(0.40 \mathrm{mg} / 100 \mathrm{~g})$, cauliflower $(0.35 \mathrm{mg} / 100 \mathrm{~g})$, 
Chinese cabbage $(0.24 \mathrm{mg} / 100 \mathrm{~g})$, Red cabbage $(0.05 \mathrm{mg} / 100 \mathrm{~g})$, and white cabbage (0.04 mg/100 g) [43].

\subsection{Micro- and Macro-Elements}

Macro-elements, also called macronutrients, are those nutrients that the plants need in greater quantities for essential structural and energetic role. They are indispensable elements for the growth and development of the metabolic functions of plants. The fundamental nutrients are represented by nitrogen $(\mathrm{N})$, phosphorus $(\mathrm{P})$ and potassium $(\mathrm{K})$.

Minerals, such as Boron (B), Copper $(\mathrm{Cu})$, Cobalt $(\mathrm{Co})$, Iron (Fe), Manganese (Mn), Zinc (Zn), and Selenium (Se), are required by plants in very small quantities and are known as microelements. Although trace elements are present in small quantities in plants, they play key roles in plant life; this is also demonstrated by the symptoms associated with deficiency phenomena. Their availability depends on the conditions of the soil. The high capacity of Brassicaceae to accumulate the metals present in the soil led this family to be considered a good heavy metal hyperaccumulator, giving the significant number of genera (11) and species (90) of those kinds of plants belong to Brassicaceae family [45].

However, micro- and macro-elements also play important roles in the human body. The elements $\mathrm{K}, \mathrm{Ca}, \mathrm{Mg}, \mathrm{Fe}, \mathrm{Zn}$, Se, and $\mathrm{Mn}$ are fundamental in the regulation of many metabolic activities, in bones and teeth health, in cancer prevention, in the production of red blood cells, and participating as enzyme co-factors. Among Brassicaceae, kale is the richest in almost all the main macro and micro elements, with a particularly high amount of calcium (95-539 mg/100 g of edible portion), magnesium (20-67 mg/100 g of edible portion), phosphorus (13-92 mg/100 g of edible portion), potassium (20-491 mg/100 g of edible portion), zinc $(0.3-0.9 \mathrm{mg} / 100 \mathrm{~g}$ of edible portion), iron $(0.4-3.1 \mathrm{mg} / 100 \mathrm{~g}$ of edible portion), manganese (0.4-1.9 mg/100 g of edible portion), copper $(0.02-1.03 \mathrm{mg} / 100 \mathrm{~g}$ of edible portion), and selenium (0-0.94 $\mathrm{mg} / 100 \mathrm{~g}$ of edible portion). Mustard green is the richest in iron (1.64 mg/100 g of edible portion), Turnip in sodium $(67 \mathrm{mg} / 100 \mathrm{~g}$ of edible portion) and Broccoli in selenium (2.5 $\mathrm{mg} / 100 \mathrm{~g}$ of edible portion) $[36,46]$.

\subsection{Glucosinolates (GLS) and Isothiocyanates (ITCS)}

Glucosinolates (GLS) are one of the most important secondary metabolites in Brassicaceae derived from amino acid biosynthesis [14,47]. GLS are glucosidic compounds containing sulphur, present in Brassica leaves, compartmentalized in the vacuole, at concentrations that are able to prevent the development of pathogens, diseases and pests [48]. Their concentrations vary among Brassica species [49], according to the developmental stage, tissue type, exposure to salt stress, environmental factors, or plant signalling molecules, including treatment with salicylic acid (SA), jasmonic acid (JA) and methyl-jasmonic acid (MeJA) [50-52]. However, their amount generally ranges from the $4.7-32.2 \mathrm{mg} / 100 \mathrm{~g}$ of Mustard spinach, 8.7-12.8 mg/100 g of Rocket, 9.7-33.7 mg/100 g of Chinese cabbage, up to the $65.4-151.1 \mathrm{mg} / 100 \mathrm{~g}$ of Kale, $149.4 \mathrm{mg} / 100 \mathrm{~g}$ of Chinese broccoli and 87.6-332.8 mg/100 g of Radish [53,54]. GLS can be divided into three chemical classes: arylaliphatic, indole and aliphatic, based on their amino acid precursor (aromatic amino acid, tryptophan and methionine, respectively) [55], as reported in Table 2. In Brassica vegetables, the most important GLS belong to the methionine-derived ones [56]. Some authors declared that the most popular food processing methods, such as boiling, blanching, and steaming, can significantly affect the final content of GLS. A mild-processing technique, such as blanching, is recommended in order to minimize the loss of GLS or their derivatives [57]. 
Table 2. Principal glucosinolates identified in leaves of Brassica vegetable crops.

\begin{tabular}{|c|c|c|c|c|c|c|c|c|c|c|c|c|c|c|c|}
\hline \multirow{2}{*}{ Crop } & \multicolumn{10}{|c|}{ Aliphatic Glucosinolates } & \multicolumn{4}{|c|}{ Indole Glucosinolates } & \multirow{2}{*}{$\begin{array}{c}\begin{array}{c}\text { Arylaliphatic } \\
\text { Glucosinolates }\end{array} \\
\text { GST }\end{array}$} \\
\hline & GIB & PRO & SIN & GAL & GRA & GNA & GBN & GIV & GER & GNL & GBS & NGBS & 4HGBS & 4MGBS & \\
\hline \multicolumn{16}{|l|}{ Brassica oleracea } \\
\hline White cabbage [58-61] & + & + & + & + & + & + & + & + & + & - & + & + & + & + & + \\
\hline Savoy cabbage [58-61] & + & + & + & - & + & + & + & + & - & - & + & + & - & + & + \\
\hline Red cabbage $[58,60,61]$ & + & + & + & - & + & + & - & + & - & - & + & + & - & - & - \\
\hline Kale $[58,60-62]$ & + & + & + & - & + & + & - & + & - & - & + & + & + & + & + \\
\hline Tronchuda cabbage $[60,63]$ & + & + & + & + & + & + & + & + & - & - & + & + & + & + & + \\
\hline Broccoli $[62,64]$ & + & + & + & + & + & + & + & - & + & + & + & + & + & + & + \\
\hline Brussel sprouts $[61,62,64]$ & + & + & + & - & + & + & - & + & - & - & + & + & - & - & - \\
\hline Cauliflower $[61,64]$ & + & + & + & - & + & - & - & + & - & - & + & + & - & - & - \\
\hline Kohlrabi [61] & + & + & + & + & + & + & - & + & - & - & + & + & + & + & - \\
\hline \multicolumn{16}{|l|}{ Brassica rapa } \\
\hline Turnip [59] & + & + & - & - & - & + & + & - & + & + & + & + & + & + & + \\
\hline Turnip greens [65] & + & + & - & + & + & + & + & + & - & + & + & + & + & - & + \\
\hline \multicolumn{16}{|l|}{ Brassica napus } \\
\hline Swede [59] & - & + & - & - & + & - & + & - & - & + & + & + & + & + & + \\
\hline Leaf rape [67] & - & + & - & + & - & + & + & + & - & + & + & + & - & + & + \\
\hline
\end{tabular}

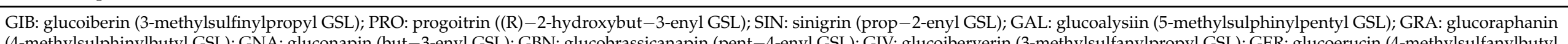

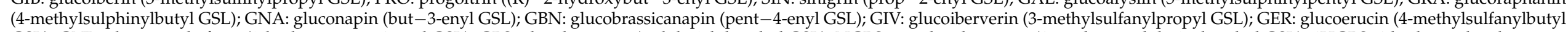

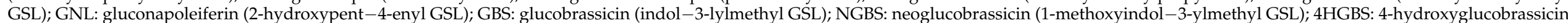
(4-hydroxyindol-3-ylmethyl GSL); 4MGBS: 4-methoxyglucobrassicin (4-methoxyindol-3-ylmethyl GSL); GST: gluconasturtiin (2-phenylethyl GSL). 
GLS have no direct functions to human health: the health effects are exerted by their hydrolysis breakdown products, the isothiocyanates (ITCs). These are aromatic volatile compounds containing sulphur, derived from the hydrolytic action of the enzyme myrosinase on GLS. The plant myrosinase acts in the human gut and hydrolyses GLS in ITCs during human ingestion. However, during the cooking of the vegetables, the exposure to heat treatment can inactivate the plant myrosinase, so the ITCs are obtained thanks to the action of myrosinase produced by the human gut flora. Unfortunately, its activity and efficiency are lower than plant myrosinase $[68,69]$. It is possible to obtain many ITCs, and their production strictly depends on the original GLS, the substrate, the $\mathrm{pH}$ conditions, the availability of ferrous ions, and the level of activity of the ESP (epithiospecifier protein), a specific protein factor $[52,70]$.

ITCs are mainly responsible for the bitterness, and spicy and typical aroma and smell of Brassica vegetables [63]. They possess protective and preventing effects against several kinds of cancer e.g., prostate, intestinal, liver, lung, breast, and bladder, chronic inflammation and neurodegeneration, acting on the apoptotic phase of cell developmental cycle; they are also effective in the reduction in cholesterol [19,71,72].

The most studied ITCs in medical research is sulforaphane [73,74], mainly represented in broccoli and Brussel sprout. It is the most important ITCs considering its health benefits, it derives from the glucoraphanin [75]. Sulforaphane is an indirect antioxidant, because it acts as a catalyst in the stimulation of cellular antioxidant system. In particular, sulforaphane stimulates some enzymes active against tumoral cell proliferation $[65,66]$.

\section{Sensorial Quality}

The quality of vegetables for the consumer not only concerns the nutritional aspects, but also includes the sensorial parameters that can be defined by several indicators.

The principal sensorial parameters are:

- Firmness, which indicates the resistance of vegetables to mechanical damages; it assumes a great importance during the post-harvest management.

- Colour, which indicates the freshness of the product and the quality of the storage conditions; it visually attracts the consumers [76].

- Sweetness, which is linked to the presence of glucose, fructose, and sucrose, and provides the sweet sensation to the consumer.

- Acidity, which indicates the acid sensation that the product stimulates in the consumer.

Considering Brassica vegetable quality, fundamental sensorial parameters are those related to aroma and taste. All of these parameters can be investigated through analytical measurements or the implementation of a panel test.

\subsection{Brassica Aroma}

The typical aroma is one of the main reasons for the consumers' rejection against Brassica vegetables [77]. Raw vegetables are rich in aroma compounds, which are usually produced because of enzymatic reactions. The typical sulphurous and pungent odour of Brassicaceae crops are often attributed to GSL/ITC content. These traits predominantly stem from sulphur-compound degradation products, such as from S-methyl-L-cysteine sulfoxide (SMCSO) [78], and formation can be facilitated by factors, such as bacterial metabolism, plant senescence, cooking, and enzymatic breakdown because of tissue damage (e.g., cutting) [79-81]. Sulphides are generally undesirable odour attributes [82], and compounds such as methanethiol, dimethyl sulphide (DMS), dimethyl trisulphide (DMTS), and dimethyl disulphide (DMDS) are regularly linked with sulphurous aromas and overcooked off-flavours. The main responsible of the fresh cabbage odour is the allyl isothiocyanate, a hydrolysis product of sinigrin thanks to the action of myrosinase $[83,84]$. Additionally, green note is a particularly important characteristic to recognize in Brassica and is conferred by alcohols and aldehydes formed by the enzymatic degradation of free fatty acids [83]. 
Cooking is the main adopted form to eat Brassica, because makes those vegetables more easily digestible and causes a flavour change in them, increasing the consumers' acceptance [85]. Reductions in alcohols, aldehydes and nitriles concentration were reported in cooked Brassica, as well as of the sulphides amount (except in broccoli) [85]. The concentration of isothiocyanate was found to increase after cooking [85]. Additionally, the storage of vegetables in frozen form could impact their volatile profile, in particular, influencing the alcohol, aldehydes, and isothiocyanates content [85].

\subsection{Brassica Taste}

As previously stated, Brassica vegetables contain health-related compounds that possess undesirable sensory characteristics. Bitterness is particularly accentuated in Brassica; this sensation is caused by ITCs that derive from sinigrin, gluconapin, progoitrin, glucobrassicin, neoglucobrassicin at different intensities [86,87]. Many studies identified the relation between the bitter taste and sinigrin and goitrin in cooked Brussels sprout, and between bitterness and sinigrin and neoglucobrassicin in cooked cauliflower [88]. Several studies affirm that the GLS and their breakdown products are not the only ones responsible for the bitter taste and Brassica aroma, but these resulted from a synergistic activity of various phytochemicals (indole hydrolysis products, flavonoids, etc.) $[65,89]$.

The overall taste of Brassica vegetables is not only linked to bitter compounds but derives from the interaction between the bitter and the sweet tastes [88]. Some evidence demonstrated how the taste is the main driver of liking a food product [90,91], and that there is an innate preference for sweet taste in respect to bitter and sour taste [92,93]. This explains why a bitter taste in vegetables could deter most consumers from buying them. Some studies demonstrated that consumers prefer Brassica with low amounts of bitter GLS and higher concentrations of sucrose and, more generally, that the sweet taste is a favourable characteristic for the consumer's appreciation of Brassica [87,91].

\section{Factors Influencing the Phytochemical Compounds of Brassica Vegetables}

The quality of the final product can be influenced by several factors such as genetic, environmental, and agricultural (Figure 1).

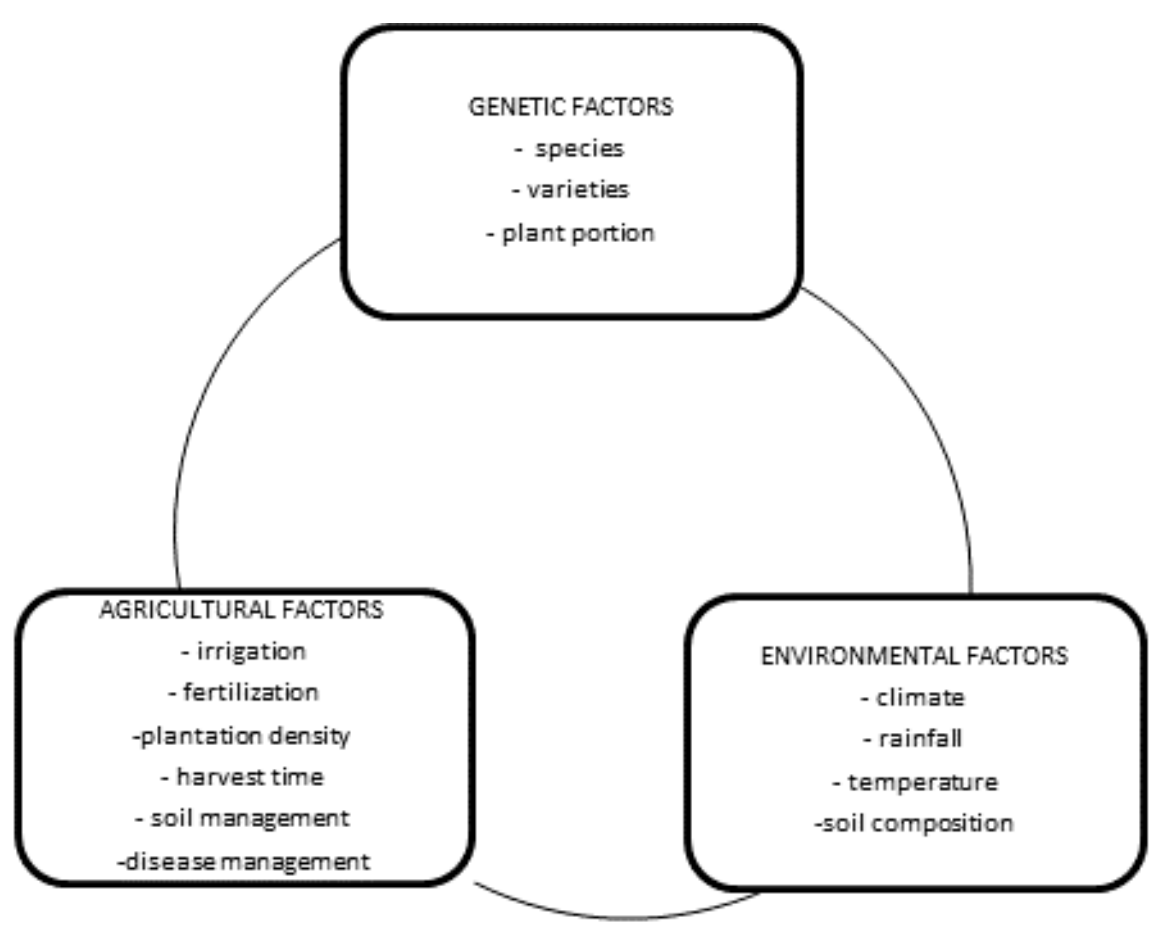

Figure 1. Factors that influence the quality of the final product. 


\subsection{Genetic Factors}

As for all other crops, Brassica quality is influenced by several factors, but the principal is represented by the genotype characteristics. Many breeding programs are working towards the creation and selection of new better productive and qualitative genotypes. These programs are particularly implemented in the Mediterranean Area, where many spontaneous and wild Brassica provide genetic diversity and variability, allowing for the development of new pre-breeding and advanced breeding materials. Particularly in Italy and Spain, it is possible to find countless ecotypes and populations of Brassica oleracea and Brassica rapa species, handed down by generations of farmers [49].

These two species have been widely studied and showed a wide diversity in terms of nutritional quality.

\subsubsection{Brassica Oleracea Species}

Kale could be considered the ancestor of several $B$. oleracea vegetable crops because it has been found to be very similar to the B. oleracea wild type and to several wild Brassica species $(n=9)$ [94].

Several differences among varieties within this species were reported, e.g., the highest content of total phenolic was found in curly kale that showed a concentration 10-times higher than cauliflower and white cabbage [95]. Although the methodologies of analysis used in many studies were different, all of them agree on the lower content of phytochemicals in white cabbage, in respect to broccoli, Brussel sprouts, curly kale and red cabbage. There are controversial results regarding cauliflower as it showed high activity in liposomal phospholipid suspension system, but low activity in oxygen radical absorption capacity (ORAC method) [14,15].

As mentioned above, the variability is also expressed among genotypes of the same species in broccoli [96], cauliflower [97], cabbage [26] depending on their characteristics; in general, the higher content of antioxidants is detected in the varieties with red or purple pigmentation. Broccoli is important for its cancer-protective compounds; in particular, for its content of glucoraphanin, and its active form sulforaphane. Sicilian landraces of violet cauliflower could be considered an environmentally friendly crop, being characterized by high plant rusticity and adaptability to the Mediterranean climatic condition that allows one to limit the use of pesticides and fertilizers for its cultivation [98].

\subsubsection{Brassica rapa Species and Other Cruciferous Crops}

Brassica rapa species include turnip tops and leaves ("cima di rapa" and "friariello"), turnip, pak choi, Chinese cabbage, choy-sum and mizuna, evidencing a wide variability among close species [99] and varieties of the same species [100]. Phenolic compounds are mainly affected by the interaction between environment and genotype; this means that their variability strictly depends on the environmental conditions, hence they possess low heritability.

Choy sum, a Brassica rapa variety, showed the highest antioxidant potential compared to broccoli, cabbage, and cauliflower [101]. Some studies found that watercress showed a higher antioxidant potential in comparison to salad rocket; however, these two varieties, together with wild rocket and mizuna, are good sources of antioxidants [102,103]. In $B$. rapa, the aliphatic glucosinolates (GLS) is the predominant form, with gluconapin as the most abundant, followed by glucobrassicanapin [104]. B. rapa varieties have shown a high concentration of isorhamnetin, irrespective of the plant organs considered [105].

\subsubsection{Plant Portion and Plant Developmental Stage}

The variation in nutritional and phytochemical content does not differ only among species and varieties of the same species, but also can change during the growth period [6] and based on plant portion [50], as reported below.

For most of these crops, the more interesting parts of the plant for the nutritional quality are not consumed. For example, seeds seem to possess the highest content of 
phytochemical compounds but are not usually consumed and appreciated by consumers; this aspect is confirmed in kale, where seeds possess higher antioxidant capacity than leaves [22]. In turnip, flower buds registered the highest antioxidant content, in respect to leaves, stems and roots [106].

GLS content also differs based on plant portion. Seeds possess the highest concentration of GLS, followed by inflorescences, siliques, leaves, roots, stems and petioles [107]. Indeed, the concentration of aliphatic GLS in kale (B. oleracea acephala) leaves increases over time, from seedling to early flowering stages. At that stage, the aliphatic GLS content in leaves of $B$. oleracea declined drastically over time as the content in the flower buds increased [50].

A comparison study on turnip tops and turnip greens also reported several and appreciated differences in phytochemicals compounds. Turnip tops gave a higher GLS value $(26.02 \mu \mathrm{mol} / \mathrm{g} \mathrm{dw})$ than turnip greens $(17.78 \mu \mathrm{mol} / \mathrm{g} \mathrm{dw})$. The opposite trend was reported for total phenolic, whereby turnip greens showed a higher content $(43.81 \mu \mathrm{mol} / \mathrm{g} \mathrm{dw})$ than turnip tops $(37.53 \mu \mathrm{mol} / \mathrm{g} \mathrm{dw})$ [104].

Several studies confirmed the possibility to detect differences within the same portion of plant. In tronchuda cabbage, the mainly consumed portion are the internal leaves, utilised for salad or cooking; nonetheless, these have an antioxidant capacity lower than the external ones, which are usually discarded [22]. The same results were observed in Chinese cabbage, whereby the variation in bioactive compounds was also evident among different layers of the same head cabbage; phenolic acids and flavonoids were higher in the outer leaves, followed by the mid- and inner leaves. This result could be explained by the higher exposure of outer leaves to sunlight, which stimulates the production of antioxidants [108].

The stage of growth can influence the content and concentration of phytochemical compounds in Brassica, and the knowledge of this aspect is fundamental in choosing the proper harvesting moment for obtaining products with the highest quality. Indeed, the juvenile cabbage possesses more flavonols than the mature one [26].

Total GLS content also varies in the function of the stage of growth and increases from vegetative to reproductive stages and maturity. Consequently, the highest content is found either in flower buds, or in leaves harvested at the optimum consumption stage, 180 days after the sowing of kale [50]. In broccoli heads, the highest glucoraphanin content was also observed 180 days after sowing, with a following decline during flowering [109].

Vallejo et al. [110] found an increase in ascorbic acid and phenol compounds during the development of the inflorescence in three broccoli cultivars.

Carotenoids are also affected by the plant developmental stage. In kale, the highest content of lutein was registered in 1- to 2-week-old leaves, and the highest content of $\beta$-carotene was found in 2- to 3-week-old leaves [111].

Some of the health-promoting factors may be present 10-times higher in sprouts than in mature vegetables. Sprouting resulted in an overall increase in the total phenolic content and antioxidant capacity and, although germination time was not a discriminating factor, longer germination times resulted in the lower antioxidant capacity of the sprouts [112].

\subsection{Environmental and Agricultural Factors}

Seasonal variation, light exposure, temperature, water availability [113], phytosanitary measures, sowing date and harvesting period [114] are all factors linked to environmental conditions that can influence the quality, in particular nutritional content and profile, of Brassica vegetables [6]. Different responses to seasonal variations were reported in several Brassica crops, such as broccoli, kale, and turnip [115]; this effect is determined mainly by temperatures and day length during the period before harvest.

Countless studies agree that spring season crops, growing at intermediate temperatures, high light intensity, during longer days and in dry conditions (or low average of rainfall) during their vegetative period, contain an increased total GLS and phytochemicals concentration [50,104,114]. For example, in canola (Brassica napus), it was found that GLS 
concentration increased when a temperature of $40{ }^{\circ} \mathrm{C}$ was maintained for $4 \mathrm{~h}$ on five successive days, giving a total of 15 -degree days of stress ( $\left.15 \mathrm{DD} / 40^{\circ} \mathrm{C}\right)$ [116]. Some authors reported that higher and lower temperatures, rather than intermediate temperatures, brought about an increase in GLS concentration, e.g., growing temperatures between $7{ }^{\circ} \mathrm{C}$ and $13{ }^{\circ} \mathrm{C}$ brought about an increase in glucoraphanin and lutein in broccoli; furthermore, they acted as a trigger for biosynthetic pathways [117]. Moreover, broccoli sprouts grown at constant high $\left(29-33^{\circ} \mathrm{C}\right)$ or low $\left(11-16^{\circ} \mathrm{C}\right)$ temperatures had higher antioxidant content than sprouts grown at intermediate temperature $\left(21.5^{\circ} \mathrm{C}\right)$ [118]. The same authors confirm that the main antioxidant content is observed in sprouts that grow with a strong temperature range of $30 / 15^{\circ} \mathrm{C}$ day/night.

Autumn/winter season crops, grown at lower temperature, lower light intensity, shorter days, and higher water availability, tend to have the lowest total GLS and other phytochemicals concentration $[119,120]$. An exception is represented by a turnip that produces higher flavonoids and vitamin C content in the autumn/winter season; this crop accumulates and produces the main phytochemicals with low/moderate temperature and considerable radiation, mainly in turnip tops [121]. More precisely, in Brassica rapa, the correlation with temperature is also bound to the plant portion; indeed, the number of days with a minimum temperature below $0{ }^{\circ} \mathrm{C}$ was negatively correlated with total GLS content in turnip greens. In turnip tops, GLS content was positively correlated with the number of days with a maximum temperature above $20^{\circ} \mathrm{C}$. In the case of phenolics, no correlation was found between climatic factors and turnip greens, while in turnip tops, total flavonoids and total phenolics content seemed to be correlated with the number of days with a minimum temperature below 0 and $10{ }^{\circ} \mathrm{C}$, respectively [104]. In broccoli, freezing temperature can positively influence the concentration of sulforaphane [122].

The biotic and abiotic factors that characterize the surrounding environment can influence the quality of Brassicaceae. With respect to biotic sphere, aphid infestation brought about an increased production of primary metabolites, including amino acids, as well as some secondary metabolites, as a plant defence mechanism against these pathogens. Concerning abiotic factors, the water stress condition and metal exposure produce an initial increase in photosynthetic pigments, proteins, free amino acids and sugar content, followed by a subsequent decrease [123]. In detail, a relation between copper stress and the production of amino acids was found as free amino acid production takes part in the detoxification from excess copper [124]. In Brassica juncea, the accumulation of metals produces a 35\% increase in oil content [123]. Moderate salinity in water or soil affects the myrosinase-GLS system in broccoli, inducing the production of GLS; also, phenolic compounds increase in this stressful condition, but in the case of strong salinity both GLS and phenolics decrease [125]. Seedlings of Brassica oleracea L. var. italica subjected to water shortage (applied by increasing the time between two irrigation events) showed a decrease in inflorescence chlorophylls, carotenoids, ascorbic acid, total phenols and total soluble carbohydrates [126].

Ragusa and co-author [127] investigated the effect of different germination temperatures $\left(10,20\right.$ and $\left.30^{\circ} \mathrm{C}\right)$ on the phytochemical content as well as on reducing and antioxidant capacity of broccoli and rocket sprouts. In both seeds and sprouts, the total GLS and ascorbic acid contents did not differ between vegetables, while broccoli exhibited exceptionally higher polyphenols and a greater reduction in antioxidant capacity compared to rocket. In both species, an increase in germination temperature positively affected the glucosinolate content. Ascorbic acid increased during germination without a difference among the three tested temperatures. The phenol content increased in broccoli sprouts when grown at $30{ }^{\circ} \mathrm{C}$, while the reverse was true in rocket. The antioxidant capacities increased with germination, and higher indexes were detected at $10^{\circ} \mathrm{C}$, particularly in rocket.

\subsubsection{Cultivation System and Soil Composition}

The cultivation system influences the quality of vegetable product, in particular the concentration of primary and secondary metabolites in Brassica vegetables. 
Some authors reported a higher antioxidant (phenolic compounds, in particular flavonoids) and GLS concentration in Brassica growth in organic cultivation system than in conventional systems [128], as demonstrated in early harvested tronchuda cabbage [129]. This result could be linked to the fact that, under organic cultivation, crops are subjected to more biotic and abiotic stress; these stressing conditions lead to an increase in the production of secondary metabolites as a defence mechanism, and consequently obtaining vegetables with higher nutritional and antioxidant potential than in a conventional system.

Several studies described an opposite situation and contrasting evidence about phytochemical enhancement in organic vegetables [130,131]. In fact, Conversa et al. [132] reported that the choice of cultivation systems does not modify the antioxidant properties of raw and processed products, but differences can be found in the chlorophyll and carotenoid contents of organic "cima di rapa" landraces. The lipophilic antioxidant content was improved in organic product while the hydrophilic component, which constituted $99 \%$ of the total antioxidant capacity, was not affected by the different crop management in "cima di rapa". However, the organic system influenced the quality of products during storage: after 7 days of storage at $5{ }^{\circ} \mathrm{C}$, the organic "cima di rapa" maintained the best colour with high chlorophyll levels, probably due to a higher availability of nitrogen in organic management; on the contrary, the quality declined with a higher production of strong off-odour after 14 days of storage, in comparison to the conventional products.

Regarding the soil composition effect on Brassica quality, it was reported that the highest GLS and phenolic compounds content were detected in locations with the highest soil $\mathrm{pH}$ and available potassium; the content can be also influenced by nitrogen and sulphur applications in turnip [104]. On the contrary, in B. rapa L. Subsp. Sylvestris, flavonols (kaempferol and quercetin derivatives) were reduced by sulphur availability [113].

\subsubsection{Water Stress}

It was reported that a moderate water stress increases the concentration of bioactive compounds in Brassica, partly due to an increased concentration per unit of dry weight; if the stress becomes intensive, the secondary metabolite production should decrease [133]. Phenolic compounds and GLS content increase in the absence of irrigation, because of a reduction in vegetative growth, mainly in turnip, cabbage and broccoli [6]. The association between low availability of water in the soil during plant growth and postharvest cold storage brought about the best maintenance of antioxidant activity in Brassica. Water stress conditions also affect sugar content, as it is increased in cabbage [134].

\subsubsection{Plant Density, Intercropping and Trap Cropping}

Plant density seems to affect the plant morphology and phytochemical compound content: a higher density decreases the head size but increases the GLS content, because the competition for nutrients in high density conditions causes stress on plants which, in turn, stimulates the production of secondary metabolites [120].

Intercropping and trap cropping are strategies utilised for weed and pest control [135]; however, the presence of another crop can generate stressful conditions, such as plant competition for light, nutrients, and water, decreasing their availability and, hence, affecting the accumulation of phytochemicals in Brassica plant tissue.

\subsubsection{Fertilization Practices}

A correct fertilization plan is fundamental for obtaining high quality, healthy and safe vegetables. The nutritional and sensorial profile of Brassica is conditioned by the availability of fertilizers and nutrients as they determine the biosynthesis of secondary metabolites.

Countless studies have been conducted on the effect of sulphur fertilization on phytochemical concentration, mainly on GLS production, considering their sulphurous nature $[136,137]$. There is a correlation between the increase in sulphur supply and higher levels of total GLS [138], in turnip [136], kale [137] and broccoli, mainly when associated with a reduction in water, at the expense of yield [139]. Vallejo and co-authors [119] sug- 
gested that the effect of sulphur application on GLS varies with the development stage of broccoli plants and differs for each kind of GLS; in fact, they found an increase in total GLS content at the start of the inflorescence development, followed by a rapid decrease thereafter. Increasing sulphur fertilization brought about a positive impact in the synthesis of polyphenols, such as flavonols and phenolic acids, increasing the total antioxidant capacity in turnip top (B. rapa ssp. Sylvestis) [113], and broccoli [110]. Sulphur fertilization in pre-harvest (from $2.6 \mathrm{mmol} / \mathrm{L}$ to $6.5 \mathrm{mmol} / \mathrm{L}$ ) increases the lipophilic and hydrophilic antioxidant capacity but does not affect the nitrate and chlorophyll contents in ready-to-eat "friariello" product [140]. Sulphur deficiency induced an increased vulnerability of Brassica crops to diseases and fungal pathogens [141]. Sulphur fertilization, besides improving the antioxidant activity, it is also associated with a genotype-dependent significant reduction in leaf nitrate content, since it enhances the incorporation of nitrogen into organic compounds and consequently reducing the leaf nitrate concentration [113].

Nitrogen is the main constituent of chlorophyll structure: for this reason, its availability influences the content of carotenoids such as lutein and $\beta$-carotene, indeed high $\mathrm{NO}_{3}-\mathrm{N}: \mathrm{NH}_{4}-\mathrm{N}$ ratio led to a higher content of both [142]. Consequently, the colour and pigmentation of leafy vegetables are also improved [132]. Nitrogen fertilisation led to a decrease in the total GLS content [136]; nonetheless, it acts differently according to the type of GLS; in fact, abundant nitrogen applications increase progoitrin and decrease sinigrin concentration in Brassica napus [143]. A reduced nitrogen fertilisation generated an increase in the bioactive compound content, mainly phenolics, as nitrogen stress triggers the gene expression of flavonoid pathway enzymes [128]. Combined fertilisation with $\mathrm{NO}_{3}{ }^{-}: \mathrm{NH}_{4}{ }^{+}$ is the optimal solution to maintain plant growth and increase the total GLS content [144].

An optimal balance between nitrogen and sulphur fertilisation influences the biosynthesis of secondary metabolites [21]. GLS, for example, can be enhanced by the presence of low nitrogen and high sulphur fertilizers: this balance influences the quantity and the quality of GLS produced, according to the corresponding amino acids synthetized. Some authors reported the effect of different nitrogen/sulphur combinations on GLS content in Brassica, with an increasing amount of nitrogen (80-320 kg/ha) applications. When enough sulphur was available $(60 \mathrm{~kg} / \mathrm{ha})$, there were no effects on total GLS content, but their production moved to indolics; when the combination was with a low concentration of sulphur supply (10-20 kg/ha), the arylaliphatic and aliphatic GLS decreased [138]. Increased nitrogen/sulphur ratio pushes the plants towards the vegetative growth, at the expense of GLS production [136]. Fabek et al. [145] showed that the type of fertilisation may influence mineral composition in plants: nitrogen fertilisation was negatively associated with potassium $(\mathrm{K})$ and calcium $(\mathrm{Ca})$ content in broccoli, while sulphur fertilisation increased manganese $(\mathrm{Mn})$ and zinc $(\mathrm{Zn})$, and decreased copper $(\mathrm{Cu})$. Applications of sodium selenate $\left(\mathrm{Na}_{2} \mathrm{SeO}_{4}\right)$ produced an increase in GLS [144].

Similarly, microelements availability can influence the phytochemical concentration in Brassica, with salts stress increasing GLS content. In detail, selenium seems to increase the GLS content (in particular sulphuraphane), when applied up to a certain dose; above this level, it decreases the GLS production [51].

Furthermore, some Brassica species are used as metal hyperaccumulator, and the type and amount of metal in the soil affects the concentration of glucosinolates in plant tissues. In particular, it was reported that glucosinolate concentrations in roots and shoots of Thlaspi caerulescens responded in different way to enhanced $\mathrm{Zn}$ accumulation: decreased glucosinolate levels were observed in leaves of plants accumulating high $\mathrm{Zn}$ concentrations, while increased levels were detected in roots, with $\mathrm{Zn}$ accumulation [146]. Similarly, the content of total glucosinolates, mostly due to indolic glucosinolates as glucobrassicin, was increased only in the roots of Chinese cabbage, when subjected to high soil copper stress [147]. In two B. juncea cultivars subjected to high arsenic levels, the increased levels of thiol related proteins, sulphur content and phytochemicals (phenolics and ascorbic acid) in leaves allow us to better tolerate the oxidative stress induced in the plant; different 
response pattern of total and individual GSLs content was observed in both cultivars under arsenic stress [148].

Besides the classical fertilizers, in the last years, new proposed products that are beneficial on crops, such as improving safety, enhancing growth and production, improving the defence against weeds and pests and nutritional quality, were developed. Among these, signalling molecules, biocontrol agents, and biostimulants are now gaining high interest for improving plant resilience and quality. Leaves and cotyledons of B. napus, B. rapa and $B$. juncea showed an up to 20-fold increase in glucobrassicin content after treatment with JA (Jasmonic Acid), or MeJA (Methyl Jasmonate) [149]. In contrast, treatment with ABA (Abscisic Acid) reduced the accumulation of indole GLS in B. napus [150].

In summary, the levels of hormones, such as JA, SA (Salicylic Acid) and ABA, seem to be related to the regulation of GLS and of other bioactive compound content [151]. Consequently, hormonal elicitation can be a useful tool to induce the synthesis of bioactive compounds interesting for human health.

Concerning the application of biocontrol agents, Gallo et al. [152] affirmed that the use of Trichoderma and its metabolites led to an increase in GLS in plants. This could probably be due to their capability of inducing resistance mechanisms, stimulating the synthesis of salicylic and jasmonic acids and the cascade of events leading to the production of various metabolites; only ascorbic acid was lower compared to control plants.

Additionally, in Brassica spp. cultivation is increasing the use of biocontrol agents, there is also the utilisation of seaweeds extract, mycorrhizae, nematodes [153], humic acids such as vermicompost foliar sprayed [154], and protein hydrolysates, all compounds now classified as "biostimulants", useful to increase plant yield and the accumulation of bioactive compounds [155].

Brassica species can contrast the main soil-borne agents thanks to their secondary metabolites that act as biofumigants. A study reported the effectiveness of the flour of dry plants of Brassica juncea, Eruca sativa, Raphanus sativus and Brassica macrocarpa in nematodes control (Meloidogyne spp.) on tomatoes. Minced flour was distributed before planting (60 and $90 \mathrm{~g} \mathrm{~m}^{-2}$ ) and was successful for the sinigrin presence [156].

\section{Conclusions}

Brassica vegetables are a good source of many phytochemical compounds that exert positive effects on the final consumer's health. This study presented an investigation on the presence of these bioactive compounds, analysing how they affect the sensorial and nutritional quality, and on the factors that can modify their concentration in Brassica food vegetables, such as genetic, environmental and agronomic factors.

There is a large possibility to improve the nutritional and sensorial quality of Brassica vegetables through the implementation of appropriate agronomic practices; nevertheless, the effects of the treatments are strictly genotype-dependent, and a good selection of the genotype before the start of cultivation is required. Furthermore, the environmental factors could influence to different extents the quality of Brassica genotypes, and they should be considered in the evaluation of the phytochemical compounds amount.

All this information is useful for developing new fresh and processed products with increased nutritional and sensorial quality, according to the final users' needs and the final purpose of consumption. If the consumer will be informed and made conscious of the healthy potential of the phytochemical compounds present in Brassica, they may be willing to accept these products despite the bitter taste and the intense aroma, which are often responsible for a low consumer acceptance. 
Author Contributions: Conceptualization, M.V. (Marino Visciglio), B.M., F.C., and M.V. (Massimo Vagnoni); Methodology, F.B. (Francesca Biondi), F.C., E.M., and L.M.; Investigation, F.B. (Francesca Biondi), F.B. (Francesca Balducci), and L.M.; Resources, M.V. (Marino Visciglio), and B.M.; Data Curation, F.B. (Francesca Biondi), F.C., and L.M.; Writing-Original Draft Preparation, F.B. (Francesca Biondi), and L.M.; Writing-Review \& Editing, B.M., and L.M.; Visualization, L.M.; Supervision, M.V. (Marino Visciglio), F.C., and B.M.; Project Administration, M.V. (Marino Visciglio), M.V. (Massimo Vagnoni), E.M., and B.M.; Funding Acquisition, M.V. (Marino Visciglio), and B.M. All authors have read and agreed to the published version of the manuscript.

Funding: This research received no external funding.

Institutional Review Board Statement: Not applicable.

Informed Consent Statement: Not applicable.

Acknowledgments: The authors thank Cecilia Limera and Maria Teresa Ariza Fernandez for extensively revise the manuscript.

Conflicts of Interest: The authors declare no conflict of interest.

\section{References}

1. Dauchet, L.; Amouyel, P.; Hercberg, S.; Dallongeville, J. Fruit and vegetable consumption and risk of coronary heart disease: A meta-analysis of cohort studies. J. Nutr. 2006, 136, 2588-2593. [CrossRef] [PubMed]

2. He, F.J.; Nowson, C.A.; MacGregor, G.A. Fruit and vegetable consumption and stroke: Meta-analysis of cohort studies. Lancet 2006, 367, 320-326. [CrossRef]

3. Farnham, M.W.; Wilson, P.E.; Stephenson, K.K.; Fahey, J.W. Genetic and environmental effects on glucosinolate content and chemoprotective potency of broccoli. Plant Breed. 2004, 123, 60-65. [CrossRef]

4. FAOSTAT-Food and Agriculture Organization of the United Nations. Top exports of Cabbages and Other Brassicas. In FAOSTAT Database; FAOSTAT: Rome, Italy, 2011.

5. FAOSTAT_Food and Agriculture Organization of the United Nations. Top exports of Cabbages and Other Brassicas. In FAOSTAT Database; FAOSTAT: Rome, Italy, 2019.

6. Francisco, M.; Tortosa, M.; Martinez-Ballesta, M.; Velasco, P.; Garcia-Viguera, C.; Moreno, D.A. Nutritional and phytochemical value of Brassica crops from the agri-food perspective. Ann. Appl. Biol. 2017, 170, 273-285. [CrossRef]

7. Ciancaleoni, S.; Chiarenza, G.L.; Raggi, L.; Branca, F.; Negri, V. Diversity characterisation of broccoli (Brassica oleracea L.var. italica Plenck) landraces for their on-farm (in situ) safeguard and use in breeding programs. Genet. Resour. Crop. Evol. 2014, 61, 451-464. [CrossRef]

8. Fahey, J.W. Brassicas. In Encyclopedia of Food Sciences and Nutrition, 2nd ed.; Caballero, B., Ed.; Academic Press: Cambridge, MA, USA, 2003; pp. 606-615, ISBN 9780122270550.

9. Köpke, U. Organic foods: Do they have a role? Forum Nutr. 2005, 57, 62-72.

10. Ou, B.X.; Huang, D.J.; Hampsch-Woodill, M.; Flanagan, J.A.; Deemer, E.K. Analysis of antioxidant activities of common vegetables employing oxygen radical absorbance capacity (ORAC) and ferric reducing antioxidant power (FRAP) assays: A comparative study. J. Agric. Food Chem. 2002, 50, 3122-3128. [CrossRef] [PubMed]

11. Zhou, K.; Yu, L. Total phenolic contents and antioxidant properties of commonly consumed vegetables grown in Colorado. LWT Food Sci. Techol. 2006, 39, 1155-1162. [CrossRef]

12. Azuma, K.; Ippoushi, K.; Ito, H.; Higashio, H.; Terao, J. Evaluation of antioxidative activity of vegetable extracts in linoleic acid emulsion and phospholipid bilayers. J. Sci. Food Agric. 1999, 79, 2010-2016. [CrossRef]

13. $\mathrm{Wu}$, X.; Beecher, G.R.; Holden, J.M.; Haytowitz, D.B.; Gebhardt, S.E.; Prior, R.L. Lipophilic and hydrophilic antioxidant capacities of common foods in the United States. J. Agric. Food Chem. 2004, 52, 4026-4037. [CrossRef] [PubMed]

14. Podsedek, A. Natural antioxidants and antioxidant capacity of Brassica vegetables: A review. LWT Food Sci. Technol. 2007, 40, 1-11. [CrossRef]

15. Soengas, P.; Sotelo, T.; Velasco, P.; Cartea, M.E. Antioxidant Properties of Brassica Vegetables. Funct. Plant Sci. Biotechnol. 2011, 43, 55.

16. Kurilich, A.C.; Jeffery, E.H.; Juvik, J.A.; Wallig, M.A.; Klein, B.P. Antioxidant capacity of different broccoli (Brassica oleracea) genotypes using the oxygen radical absorbance capacity (ORAC) assay. J. Agric. Food Chem. 2002, 50, 5053-5057. [CrossRef]

17. Jahangir, M.; Abdel-Farida, I.B.; Kima, H.K.; Choia, Y.H.; Verpoortea, R. Healthy and unhealthy plants: The effect of stress on the metabolism of Brassicaceae. Environ. Exp. Bot. 2009, 67, 23-33. [CrossRef]

18. Cory, H.; Passarelli, S.; Szeto, J.; Tamez, M.; Mattei, J. The Role of Polyphenols in Human Health and Food Systems: A Mini-Review. Front. Nutr. 2018, 5, 87. [CrossRef] [PubMed]

19. Moreno, D.A.; Carvajal, M.; Lopez-Berenguer, C.; García-Viguera, C. Chemical and biological characterisation of nutraceutical compounds of broccoli. J. Pharm. Biomed. Anal. 2006, 41, 1508-1522. [CrossRef] [PubMed] 
20. Heimler, D.; Vignolini, P.; Dini, M.G.; Vincieri, F.F.; Romani, A. Antiradical activity and polyphenol composition of local Brassicaceae edible varieties. Food Chem. 2006, 99, 464-469. [CrossRef]

21. Cartea, M.E.; Francisco, M.; Soengas, P.; Velasco, P. Phenolic Compounds in Brassica Vegetables. Molecules 2011, 16, 251-280. [CrossRef] [PubMed]

22. Ferreres, F.; Fernandes, F.; Sousa, C.; Valentão, P.; Pereira, J.A.; Andrade, P.B. Metabolic and Bioactivity Insights into Brassica oleracea var. acephala. J. Agric. Food Chem. 2009, 57, 8884-8892. [CrossRef]

23. Haytowitz, D.B.; Wu, X.; Bhagwat, S. USDA Database for the Flavonoid Content of Selected Foods, Release 3.3. U.S. Department of Agriculture, Agricultural Research Service. Nutrient Data Laboratory Home Page. 2018. Available online: http://www.ars. usda.gov/nutrientdata/flav (accessed on 3 May 2020).

24. Sousa, C.; Lopes, G.; Pereira, D.M.; Taveira, M.; Valentao, P.; Seabra, R.M.; Pereira, J.A. Screening of antioxidant compounds during sprouting of Brassica oleracea L. var. costata DC. Comb. Chem. High Throughput Screen. 2007, 10, 377-386. [CrossRef]

25. Ackland, M.L.; Van De Waarsenburg, S.; Jones, R. Synergistic antiproliferative action of the flavanols quercetin and kaempferol in cultured human cancer cell lines. In Vivo 2005, 19, 69-76. [PubMed]

26. Kim, D.O.; Padilla-Zakour, O.I.; Griffiths, P.D. Flavonoids and antioxidant capacity of various cabbage genotypes at juvenile stage. J. Food Sci. 2004, 69, C685-C689. [CrossRef]

27. Calderon-Montano, J.M.; Burgos-Moron, E.; Pérez-Guerrero, C.; Lòpez-Lazaro, M. A review on the dietary flavonoid kaempferol. Med. Chem. 2011, 11, 298-344. [CrossRef] [PubMed]

28. Bahorun, T.; Luximon-Ramma, A.; Crozier, A.; Aruoma, O.I. Total phenol; flavonoid; proanthocyanidin and vitamin C levels and antioxidant activities of Mauritian vegetables. J. Sci. Food Agric. 2004, 84, 1553-1561. [CrossRef]

29. Moreno, D.A.; Pérez-Balibrea, S.; Ferreres, F.; Gil-Izquierdo, A.; García-Viguera, C. Acylated anthocyanins in broccoli sprouts. Food Chem. 2010, 123, 358-363. [CrossRef]

30. Ahmadiani, N.; Robbins, R.J.; Collins, T.M.; Giusti, M.M. Anthocyanins Contents, Profiles, and Color Characteristics of Red Cabbage Extracts from Different Cultivars and Maturity Stages. J. Agric. Food Chem. 2014, 62, 7524-7531. [CrossRef]

31. Dyrby, M.; Westergaard, N.; Stapelfeldt, H. Light and heat sensitivity of red cabbage extract in soft drink model system. Food Chem. 2001, 72, 431-437. [CrossRef]

32. Milder, I.E.J.; Arts, I.C.W.; Van De Putte, B.; Venema, D.P.; Hollman, P.C.H. Lignin contents of Dutch plant foods: A database including lariciresinol; pinoresinol; secoisolariciresinol and matairesinol. Br. J. Nutr. 2005, 93, 393-402. [CrossRef]

33. Kurilich, A.C.; Tsau, G.J.; Brown, A.; Howard, L.; Klein, B.P.; Jeffery, E.H.; Kushad, M.; Walling, M.A.; Juvik, J.A. Carotene; tocopherol; and ascorbate contents in subspecies of Brassica oleracea. J. Agric. Food Chem. 1999, 47, 1576-1581. [CrossRef]

34. Vallejo, F.; Tomas-Barberan, F.A.; Garcia-Viguera, C. Potential bioactive compounds in health promotion from broccoli cultivars grown in Spain. J. Sci. Food Agric. 2002, 82, 1293-1297. [CrossRef]

35. Davey, M.W.; Van Montagu, M.; Inze, D.; Sanmartin, M.; Kanellis, A.; Smirnoff, N. Plant L-ascorbic acid: Chemistry; function; metabolism; bioavailability and effects of processing. J. Sci. Food Agric. 2000, 80, 825-860. [CrossRef]

36. Sanlier, N.; Guler Saban, M. The Benefits of Brassica Vegetables on Human Health. J. Hum. Health Res. 2018, 1, 104.

37. Bailey, L.B.; Rampersaud, G.C.; Kauwell, G.P.A. Folic acid supplements and fortification affect the risk for neural tube defects; vascular disease and cancer: Evolving science. J. Nutr. 2003, 133, 1961S-1968S. [CrossRef] [PubMed]

38. Atteia, B.M.R.; El-Kak, A.E.-A.A.; Lucchesi, P.A.; Delafontane, P. Antioxidant activity of folic acid: From mechanism of action to clinical application. FASEB J. 2009, 23, 103-107.

39. Quang, D.D. Antioxidant properties of folic acid: A DFT study. Vietnam J. Sci. Technol. 2018, 56, 39. [CrossRef]

40. Rice-Evans, C.; Sampson, J.; Bramley, P.M.; Holloway, D.E. Why do we expect carotenoids to be antioxidants in vivo. Free Radic. Res. 1997, 26, 381-398. [CrossRef]

41. Muller, H. Determination of the carotenoid content in selected vegetables and fruit by HPLC and photodiode array detection. Food Res. Technol. 1997, 204, 88-94. [CrossRef]

42. Wills, R.B.H.; Rangga, A. Determination of carotenoids in Chinese vegetables. Food Chem. 1996, 56, 451-455. [CrossRef]

43. Piironen, V.; Syvaoja, E.L.; Varo, P.; Salminen, K.; Koivistoinen, P. Tocopherols and tocotrienols in Finnish foods: Vegetables; fruits; and berries. J. Agric. Food Chem. 1986, 34, 742-746. [CrossRef]

44. Stampfer, M.J.; Rimm, E.B. Epidemiologic evidence for vitamin E in prevention of cardiovascular disease. Am. J. Clin. Nutr. 1995, 62, 1365-1369. [CrossRef]

45. Ali, Z.; Waheed, H.; Gul, A.; Afzal, F.; Anwaar, K.; Imran, S. Brassicaceae plants. In Oilseed Crops; Ahmad, P., Ed.; John Wiley \& Sons: Hoboken, NJ, USA, 2017. [CrossRef]

46. Thavarajah, D.; Lawrence, T.; Powers, S.; Jones, B.; Johnson, N.; Kay, J.; Bandaranayake, A.; Shipe, E.; Thavarajah, P. Genetic variation in the prebiotic carbohydrate and mineral composition of kale (Brassica oleracea L. var. acephala) adapted to an organic cropping system. J. Food Comp. Anal. 2021, 96, 103718. [CrossRef]

47. Blažević, I.; Montaut, S.; Burčul, F.; Olsen, C.-E.; Burow, M.; Rollin, P.; Agerbirk, N. Glucosinolate structural diversity, identification, chemical synthesis and metabolism in plants. Phytochemistry 2020, 169, 112100. [CrossRef] [PubMed]

48. Sisti, M.; Amagliani, G.; Brandi, G. Antifungal activity of Brassica oleracea var. botrytis fresh aqueous juice. Fitoterapia 2003, 74, 453-458.

49. Branca, F.; Ragusa, L.; Tribulato, A.; Velasco, P.; Cartea, M.E. Glucosinolate profile in different mediterranean brassica species $(n=9)$. Acta Hortic. 2013, 1005, 279-284. [CrossRef] 
50. Velasco, P.; Cartea, M.E.; Gonzalez, C.; Vilar, M.; Ordàs, A. Factors affecting the glucosinolate content of kale (Brassica oleracea acephala group). J. Agric. Food Chem. 2007, 55, 955-962. [CrossRef] [PubMed]

51. López-Berenguer, C.; Martínez-Ballesta, M.C.; García-Viguera, C.; Carvajal, M. Leaf water balance mediated by aquaporins under salt stress and associated glucosinolate synthesis in broccoli. Plant Sci. 2008, 174, 321-328. [CrossRef]

52. Mithen, R. Glucosinolates-Biochemistry; Genetics and biological activity. Plant Growth Regul. 2001, 34, 91-103. [CrossRef]

53. Verkerk, R.; Schreiner, M.; Krumbein, A.; Ciska, E.; Holst, B.; Rowland, I.; de Schrijver, R.; Hansen, M.; Gerhäuser, C.; Mithen, R.; et al. Glucosinolates in Brassica vegetables: The influence of the food supply chain on intake, bioavailability and human health. Mol. Nutr. Food Res. 2009, 53, 219-265. [CrossRef] [PubMed]

54. Blažević, I.; Montaut, S.; Burčul, F.; Rollin, P. Glucosinolates: Novel sources and biological potential. In Glucosinolates; Mérillon, J.-M., Ramawat, K.G., Eds.; Springer International Publishing: Cham, Switzerland, 2017; pp. 3-60.

55. Giamoustaris, A.; Mithen, R. The effect of modifying the glucosinolate content of leaves of oilseed rape (Brassica napus ssp. oleifera) on its interaction with specialist and generalist pests. Ann. Appl. Biol. 1995, 126, 347-363. [CrossRef]

56. Mithen, R.; Faulkner, K.; Magrath, R.; Rose, P.; Williamson, G.; Marquez, J. Development of isothiocyanate-enriched broccoli and its enhanced ability to induce phase 2 detoxification enzymes in mammalian cells. Theor. Appl. Gen. 2003, 106, 727-734. [CrossRef]

57. Sikorska-Zimny, K.; Beneduce, L. The glucosinolates and their bioactive derivatives in Brassica: A review on classification, biosynthesis and content in plant tissues, fate during and after processing, effect on the human organism and interaction with the gut microbiota. Crit. Rev. Food Sci. Nutr. 2020, 25, 1-24. [CrossRef] [PubMed]

58. VanEtten, C.H.; Daxenbichler, M.E.; Tookey, H.L.; Kwolek, W.F.; Williams, P.H.; Yoder, O.C. Glucosinolates: Potential toxicants in cabbage cultivars. J. Am. Soc. Hort. Sci. 1980, 105, 710-714.

59. Sones, K.; Heaney, R.K.; Fenwick, G.R. The glucosinolate content of UK vegetables: Cabbage (Brassica oleracea); swede (B. napus) and turnip (B. campestris). Food Addit. Contam. 1984, 3, 289-296. [CrossRef]

60. Cartea, M.E.; Velasco, P.; Obregòn, S.; del Rìo, M.; Padilla, G.; de Haro, A. Seasonal variation in glucosinolate content in Brassica oleracea crops grown in northwestern Spain. Phytochemistry 2008, 69, 403-410. [CrossRef] [PubMed]

61. Ciska, E.; Martyniak-Przybyszewska, B.; Kozlowska, H. Content of glucosinolates in cruciferous vegetables grown at the same site for two years under different climatic conditions. J. Agric. Food Chem. 2000, 48, 2862-2867. [CrossRef] [PubMed]

62. Carlson, D.G.; Daxenbichler, M.E.; Tookey, H.L. Glucosinolates in turnip tops and roots: Cultivars grown for greens and/or roots. J. Am. Soc. Hort. Sci. 1987, 112, 179-183.

63. Rosa, E.A.S.; Heaney, R.K. Seasonal variation in protein; mineral and glucosinolate composition of Portuguese cabbage and kale. Anim. Feed Sci. Technol. 1996, 57, 111-127. [CrossRef]

64. Kushad, M.M.; Brown, A.F.; Kurilich, A.C.; Juvik, J.A.; Klein, B.; Wallig, M.A.; Jeffery, E.H. Variation of glucosinolates in vegetable subspecies of Brassica oleracea. J. Food Agric. Chem. 1999, 47, 1541-1548. [CrossRef]

65. Padilla, G.; Cartea, M.E.; Velasco, P.; de Haro, A.; Ordàs, A. Variation of glucosinolates in vegetable crops of Brassica rapa. Phytochemistry 2007, 68, 536-545. [CrossRef] [PubMed]

66. Rosa, E.A.S. Glucosinolates from flower buds of Portuguese Brassica crops. Phytochemistry 1997, 44, 1415-1419. [CrossRef]

67. Cartea, M.E.; Rodrìguez, V.M.; Velasco, P.; de Haro, A.; Ordàs, A. Variation of glucosinolates and nutritional value in nabicol (Brassica napus pabularia group). Euphytica 2008, 159, 111-122. [CrossRef]

68. Angelino, D.; Dosz, E.B.; Sun, J.; Hoeflinger, J.L.; Van Tassell, M.L.; Chen, P.; Harnly, J.M.; Miller, M.J.; Jeffery, E.H. Myrosinasedependent and -independent formation and control of isothiocyanate products of glucosinolate hydrolysis. Front. Plant. Sci. 2015, 6, 831. [CrossRef]

69. Fahey, J.W.; Zalcmann, A.T.; Talalay, P. The chemical diversity and distribution of glucosinolates and isothiocyanates among plants. Phytochemistry 2001, 56, 5-51. [CrossRef]

70. Grubb, C.D.; Abel, S. Glucosinolate metabolism and its control. Trends Plant. Sci. 2006, 11, 89-100. [CrossRef]

71. Keum, Y.S.; Jeong, W.S.; Kong, A.N.T. Chemoprevention by isothiocyanates and their underlying molecular signaling mechanisms. Mutat. Res. 2004, 555, 191-202. [CrossRef]

72. Cartea, M.E.; Velasco, P. Glucosinolates in Brassica foods: Bioavailability in food and significance for human health. Phytochem. Rev. 2008, 7, 213-229. [CrossRef]

73. Fahey, J.W.; Haristoy, X.; Dolan, P.M.; Kensler, T.W.; Scholtus, I.; Stephenson, K.K.; Talalay, P.; Lozniewski, A. Sulforaphane inhibits extracellular; intracellular; and antibiotic-resistant strains of Helicobacter pylori and prevents benzo[a]pyrene-induced stomach tumors. Proc. Natl. Acad. Sci. USA 2002, 99, 7610-7615. [CrossRef] [PubMed]

74. Dinkova-Kostova, A.T.; Kostov, R.V. Glucosinolates and isothiocyanates in health and disease. Trends Mol. Med. 2012, 18, 337-347. [CrossRef] [PubMed]

75. Matusheski, N.V.; Jeffery, E.H. Comparison of the bioactivity of two glucoraphanin hydrolysis products found in broccoli; sulforaphane and sulforaphane nitrile. J. Agric. Food Chem. 2001, 49, 5743-5749. [CrossRef] [PubMed]

76. Bonasia, A.; Conversa, G.; Lazzizera, C.; Elia, A. Pre-harvest nitrogen and Azoxystrobin application enhances postharvest shelf-life in butterhead lettuce. Postharvest Biol. Technol. 2013, 85, 67-76. [CrossRef]

77. Wieczorek, M.N.; Walczak, M.; Skrzypczak-Zielinska, M.; Jelen, H.H. Bitter taste of Brassica vegetables: The role of genetic factors; receptors; isothiocyanates; glucosinolates; and flavor context. Crit. Rev. Food Sci. Nutr. 2018, 58, 3130-3140. [CrossRef] [PubMed]

78. Ghawi, S.K.; Shen, Y.; Niranjan, K.; Methven, L. Consumer acceptability and sensory profile of cooked broccoli with mustard seeds added to improve chemoprotective properties. J. Food Sci. 2014, 79, 1756-1762. [CrossRef] 
79. Stoewsand, S. Bioactive organosulfur phytochemicals in Brassica oleracea vegetables-A review. Food Chem. Toxicol. $1995,33,537$. [CrossRef]

80. Palermo, M.; Pellegrini, N.; Fogliano, V. The effect of cooking on the phytochemical content of vegetables. J. Sci. Food Agric. 2014, 94, 1057. [CrossRef] [PubMed]

81. Kubec, R.; Drhova, V.; Velisek, J. Thermal Degradation of S-Methylcysteine and Its Sulfoxide Important Flavor Precursors of Brassica and Allium Vegetables. J. Agric. Food Chem. 1998, 46, 4334. [CrossRef]

82. Hansen, M.; Laustsen, A.M.; Olsen, C.E.; Poll, L.; Sørensen, H. Chemical and sensory quality of broccoli (Brassica oleracea L. var italica). J. Food Qual. 1997, 20, 441-459. [CrossRef]

83. Akpolat, H.; Barringer, S.A. The Effect of $\mathrm{pH}$ and Temperature on Cabbage Volatiles during Storage. J. Food Sci. 2015, 80, S1878-S1884. [CrossRef]

84. Bell, L.; Oloyede, O.O.; Lignou, S.; Wagstaff, C.; Methven, L. Taste and Flavor Perceptions of Glucosinolates, Isothiocyanates, and Related Compounds. Mol. Nutr. Food Res. 2018, 62, e1700990. [CrossRef]

85. Wieczorek, M.N.; Jelen, H.H. Volatile Compounds of Selected Raw and Cooked Brassica Vegetables. Molecules 2019, $24,391$. [CrossRef]

86. Rosa, E.A.S.; Heaney, R.K.; Fenwick, G.R.; Portas, C.A.M. Glucosinolates in crop plants. Hortic. Rev. 1997, 19, 99-215.

87. Schonhof, I.; Krumbein, A.; Brückner, B. Genotypic effects on glucosinolates and sensory properties of broccoli and cauliflower. Food Nahr. 2004, 48, 25-33. [CrossRef] [PubMed]

88. Beck, T.K.; Jensen, S.; Bjoern, G.K.; Kidmose, U. The Masking Effect of Sucrose on Perception of Bitter Compounds in Brassica Vegetables. J. Sens. Stud. 2014, 29, 190-200. [CrossRef]

89. Baik, H.Y.; Juvik, J.A.; Jeffery, E.H.; Wallig, M.A.; Kushad, M.; Klein, B.P. Relating glucosinolate content and flavor of broccoli cultivars. J. Food Sci. 2003, 68, 1043-1050. [CrossRef]

90. Schatzer, M.; Rust, P.; Elmadfa, I. Fruit and vegetable intake in Austrian adults: Intake frequency; serving sizes; reasons for and barriers to consumption; and potential for increasing consumption. Public Health Nutr. 2009, 13, 480-487. [CrossRef] [PubMed]

91. Cox, D.N.; Melo, L.; Zabaras, D.; Delahunty, C.M. Acceptance of health-promoting Brassica vegetables: The influence of taste perception; information and attitudes. Public Health Nutr. 2012, 15, 1474-1482. [CrossRef]

92. Reed, D.R.; Tanaka, T.; McDaniel, A.H. Diverse tastes: Genetics of sweet and bitter perception. Physiol. Behav. 2006, 88, 215-226. [CrossRef] [PubMed]

93. Drewnowski, A. The science and complexity of bitter taste. Nutr. Rev. 2001, 59, 163-169. [CrossRef]

94. Branca, F.; Ragusa, L.; Tribulato, A. Diversity of Kale Growing in Europe as a Basis for Crop Improvement. Acta Hortic. 2013, 1005, 141-147. [CrossRef]

95. Jagdish, S.; Upadhyay, A.K.; Singh, S.; Rai, M. Total phenolics content and free radical scavenging activity of Brassica vegetables. J. Food Sci. Tech. Mysore 2009, 46, 595-597.

96. Perez-Balibrea, S.; Moreno, D.A.; Garcia-Viguera, C. Genotypic effects on the phytochemical quality of seeds and sprouts from commercial broccoli cultivar. Food Chem. 2011, 125, 348-354. [CrossRef]

97. Volden, J.; Bengtsson, G.B.; Wicklund, T. Glucosinolates; L-ascorbic acid; total phenols; anthocyanins; antioxidant capacities and colour in cauliflower (Brassica oleracea L. ssp. botrytis); effects of long-term freezer storage. Food Chem. 2009, 112, 967-976. [CrossRef]

98. Branca, F.; Chiarenza, G.L.; Pinio, M.; Alonso, M.; Argento, S. Characteristics and seed production of sicilian landraces of violet cauliflower. Acta Hortic. 2013, 1005, 519-524. [CrossRef]

99. Singh, J.; Upadhyay, A.K.; Prasad, K.; Bahadur, A.; Rai, M. Variability of carotenes. vitamin C. E and phenolics in Brassica vegetables. J. Food Compos. Anal. 2007, 20, 106-112. [CrossRef]

100. Francisco, M.; Moreno, D.A.; Cartea, M.E.; Ferreres, F.; Garcia-Viguera, C.; Velasco, P. Simultaneous identification of glucosinolates and phenolic compounds in a representative collection of vegetable Brassica rapa. J. Chromatogr. A 2009, 1216, 6611-6619. [CrossRef] [PubMed]

101. Wachtel-Galor, S.; Wong, K.W.; Benzie, I.F.F. The effect of cooking on Brassica vegetables. Food Chem. 2008, 110, 706-710. [CrossRef]

102. Martìnez-Sanchez, A.; Gil-Izquierdo, A.; Gil, M.I.; Ferreres, F. A comparative study of flavonoid compounds; vitamin C, and antioxidant properties of baby leaf Brassicaceae species. J. Agric. Food Chem. 2008, 56, 2330-2340. [CrossRef] [PubMed]

103. Martinez-Villaluenga, C.; Peñas, E.; Ciska, E.; Piskula, M.K.; Kozlowska, H.; Vidal-Valverde, C.; Frias, J. Time dependence of bioactive compounds and antioxidant capacity during germination of different cultivars of broccoli and radish seeds. Food Chem. 2010, 120, 710-716. [CrossRef]

104. Francisco, M.; Cartea, M.E.; Soengas, P.; Velasco, P. Effect of Genotype and Environmental Conditions on Health-Promoting Compounds in Brassica rapa. J. Agric. Food Chem. 2011, 59, 2421-2431. [CrossRef] [PubMed]

105. Jeffery, E.H.; Brown, A.F.; Kurilich, A.C.; Keek, A.S.; Matusheski, N.; Klein, B.P.; Juvik, J.A. Variation in content of bioactive components in broccoli. Study review. J. Food Compos. Anal. 2003, 16, 323-330. [CrossRef]

106. Fernandes, F.; Valentão, P.; Sousa, C.; Pereira, J.A.; Seabra, R.M.; Andrade, P.B. Chemical and antioxidative assessment of dietary turnip (Brassica rapa var. rapa L.). Food Chem. 2007, 105, 1003-1010. [CrossRef]

107. Brown, P.D.; Tokuhisa, J.G.; Reichelt, M.; Gershenzon, J. Variation of glucosinolate accumulation among different organs and developmental stages of Arabidopsis thaliana. Phytochemistry 2003, 62, 471-481. [CrossRef] 
108. Seong, G.U.; Hwang, I.W.; Chung, S.K. Antioxidant capacities and polyphenolics of Chinese cabbage (Brassica rapa L. ssp. pekinensis) leaves. Food Chem. 2016, 199, 612-618. [CrossRef]

109. Rybarczyk, A.; Wold, B.A.; Hansen, M.K.; Hagen, S.F. Vitamin C in broccoli (Brassica oleracea L. var. italica) flower buds as affected by postharvest light, UV-B irradiation and temperature. Postharvest Biol. Technol. 2014, 98, 82-89.

110. Vallejo, F.; Tomas-Barberan, F.; Garcia-Viguera, C. Changes in broccoli (Brassica oleracea L. var. italica) health-promoting compounds with inflorescence development. J. Agric. Food Chem. 2003, 51, 3776-3782. [CrossRef]

111. Lefsrud, M.; Kopsell, D.; Wenzel, A.; Sheehan, J. Changes in kale (Brassica oleracea L. var. acephala) carotenoid content and chlorophyll pigment concentrations during leaf ontogeny. Sci. Hort. Amst. 2007, 112, 136-141. [CrossRef]

112. Vale, A.P.; Cidade, H.; Pinto, M.; Oliveira, M.B.P.P. Effect of sprouting and light cycle on antioxidant activity of Brassica oleracea varieties. Food Chem. 2014, 165, 379-387. [CrossRef]

113. De Pascale, S.; Maggio, A.; Pernice, R.; Fogliano, V.; Barbieri, G. Sulphur fertilization may improve the nutritional value of Brassica rapa L. subsp. sylvestris. Eur. J. Agron. 2007, 26, 418-424. [CrossRef]

114. Renaud, E.N.C.; Lammerts Van Bueren, E.T.; Myers, J.R.; Paulo, M.J.; Van Eeuwijk, F.A.; Zhu, N.; Juvik, J.A. Variation in broccoli cultivar phytochemical content under organic and conventional management systems: Implications in breeding for nutrition. PLoS ONE 2014, 9, e95683. [CrossRef]

115. Rosa, E.A.S.; Rodrigues, A.S. Total and individual glucosinolate content in 11 broccoli cultivars grown in early and late season. HortScience 2001, 36, 56-59. [CrossRef]

116. Aksouh, N.M.; Jacobs, B.C.; Stoddard, F.L.; Mailer, R.J. Response of canola to different heat stresses. Aust. J. Agric. Res. 2001, 52, 817-824. [CrossRef]

117. Schonhof, I.; Klaring, H.P.; Krumbein, A.; Claußen, W.; Schreiner, M. Effect of temperature increase under low radiation conditions on phytochemicals and ascorbic acid in greenhouse grown broccoli. Agric. Ecosyst. Environ. 2007, 119, 103-111. [CrossRef]

118. Pereira, F.M.V.; Rosa, E.; Fahey, J.W.; Stephenson, K.K.; Carvalho, R.; Aires, A. Influence of temperature and ontogeny on the levels of glucosinolates in broccoli (Brassica oleracea var. italica) sprouts and their effect on the induction of mammalian phase 2 enzymes. J. Agric. Food Chem. 2002, 50, 6239-6244. [CrossRef]

119. Vallejo, F.; Tomas-Barberan, F.; Garcia-Viguera, C. Healthpromoting compounds in broccoli as influenced by refrigerated transport and retail sale period. J. Agric. Food Chem. 2003, 51, 3029-3034. [CrossRef] [PubMed]

120. Bjorkman, M.; Klingen, I.; Birch, A.; Bones, A.; Bruce, T.; Johansen, T.J.; Meadow, R.; Molmann, J.; Seljasen, R.; Smart, L.E.; et al. Phyto-chemicals of Brassicaceae in plant protection and human health. Influences of climate; environment and agronomic practice. Phytochemistry 2011, 72, 538-556. [CrossRef]

121. Francisco, M.; Cartea, M.E.; Butrón, A.M.; Sotelo, T.; Velasco, P. Environmental and genetic effects on yield and secondary metabolite production in Brassica rapa crops. J. Agric. Food Chem. 2012, 60, 5507-5514. [CrossRef] [PubMed]

122. Pék, Z.; Daood, H.; Nagyné, M.G.; Neményi, A.; Helyes, L. Effect of environmental conditions and water status on the bioactive compounds of broccoli. Cent. Eur. J. Biol. 2013, 8, 777-787. [CrossRef]

123. Singh, S.; Sinha, S. Accumulation of metals and its effects in Brassica juncea L. Czern. (cv. Rohini) grown on various amendments of tannery waste. Ecotox. Environ. Saf. 2005, 62, 118-127. [CrossRef]

124. Xiong, Z.T.; Liu, C.; Geng, B. Phytotoxic effects of copper on nitrogen metabolism and plant growth in Brassica pekinensis Rupr. Ecotox. Environ. Saf. 2006, 64, 273-280. [CrossRef]

125. Rodriguez-Hernandez, M.C.; Moreno, D.A.; Carvajal, M.; Martìnez-Ballesta, M.C. Genotype influences sulfur metabolism in broccoli (Brassica oleracea L.) under elevated CO2 and NaCl stress. Plant. Cell Physiol. 2014, 55, 2047-2059. [CrossRef]

126. Sakr, M.Y.; Ibrahim, H.M.; ElAwady, A.E.; AboELMakarm, A.A. Growth, yield and biochemical constituents as well as postharvest quality of water-stressed broccoli (Brassica oleraceae L. var. italica) as affected by certain biomodulators. Sci. Hortic. 2021, 275, 109605. [CrossRef]

127. Ragusa, L.; Picchi, V.; Tribulato, A.; Cavallaro, C.; Lo Scalzo, R.; Branca, F. The effect of the germination temperature on the phytochemical content of broccoli and rocket sprouts. Int. J. Food. Sci. Nutr. 2016, 68, 411-420. [CrossRef]

128. Sousa, C.; Pereira, D.M.; Pereira, J.A.; Bento, A.; Rodrigues, M.A.; Dopico-Garcia, S.; Valentao, P.; Lopes, G.; Ferreres, F.; Seabra, R.M.; et al. Multivariate analysis of tronchuda cabbage (Brassica oleracea L. var. costata DC) phenolics: Influence of fertilizers. J. Agric. Food Chem. 2008, 56, 2231-2239. [CrossRef]

129. Vrchoska, V.; Sousa, C.; Valentao, P.; Ferreres, F.; Pereira, J.A.; Seabra, R.M.; Andrade, P.B. Antioxidative properties of tronchuda cabbage (Brassica oleracea L. Var. costata DC) external leaves against DPPH; superoxide radical; hydroxyl radical and hypochlorous acid. Food Chem. 2006, 98, 416-425. [CrossRef]

130. Dangour, A.D.; Dodhia, S.K.; Hayter, A.; Allen, E.; Lock, K.; Uauy, R. Nutritional quality of organic foods: A systematic review. Am. J. Clin. Nutr. 2009, 90, 680-685. [CrossRef]

131. Hoefkens, C.; Sioen, I.; Baert, K.; De Meulenaer, B.; De Henauw, S.; Vandekinderen, I.; Devlieghere, F.; Opsomer, A.; Verbeke, W.; Van Camp, J. Consuming organic versus conventional vegetables: The effect on nutrient and contaminant intakes. Food Chem. Toxicol. 2010, 48, 3058-3066. [CrossRef]

132. Conversa, G.; Bonasia, A.; Lazzizera, C.; Elia, A. Bio-physical; physiologiacal; and nutritional aspects of ready-to-use cima di rapa (Brassica rapa L. subsp. sylvestris L. Janch. var. esculenta Hort.) as affected by conventional and organic growing systems and storage time. Sci. Hortic. 2016, 213, 76-86. [CrossRef] 
133. Khan, M.A.M.; Ulrichs, C.; Mewis, I. Drought stress-Impact on glucosinolate profile and performance of phloem feeding cruciferous insects. Acta Hortic. 2011, 917, 111-117. [CrossRef]

134. Cogo, S.L.P.; Chaves, F.C.; Schirmer, M.A.; Zambiazi, R.C.; Nora, L.; Silva, J.A.; Rombaldi, C.V. Low soil water content during growth contributes to preservation of green colour and bioactive compounds of cold-stored broccoli (Brassica oleracea L.) florets. Postharvest Biol. Technol. 2011, 60, 158-163. [CrossRef]

135. Hooks, C.R.R.; Johnson, M.W. Impact of agricultural diversification on the insect community of cruciferous crops. Crop. Prot. 2003, 22, 223-238. [CrossRef]

136. Kim, S.J.; Matsuo, T.; Watanabe, M.; Watanabe, Y. Effect of nitrogen and sulphur application on the glucosinolate content in vegetable turnip rape (Brassica rapa L.). Soil Sci. Plant. Nutr. 2002, 48, 43-49. [CrossRef]

137. Kopsell, D.E.; Kopsell, D.A.; Randle, W.A.; Coolong, T.W.; Sams, C.E.; Curran-Celentano, J. Kale carotenoids remain stable while flavor compounds respond to changes in sulfur fertility. J. Agric. Food Chem. 2003, 51, 5319-5325. [CrossRef]

138. Li, S.; Schonhof, I.; Krumbein, A.; Li, L.; Stutzel, H.; Schreiner, M. Glucosinolate concentration in turnip (Brassica rapa ssp. rapifera L.) roots as affected by nitrogen and sulfur supply. J. Agric. Food Chem. 2007, 55, 8452-8457. [CrossRef]

139. Schreiner, M.; Huyskens-Keil, S.; Peters, P.; Schonhof, I.; Krumbein, A.; Widell, S. Seasonal climate effects on root colour and compounds of red radish. J. Sci. Food Agric. 2002, 82, 1325-1333. [CrossRef]

140. Barbieri, G.; Bottino, A.; Orsini, F.; De Pascale, S. Sulfur fertilization and light exposure during storage are critical determinants of the nutritional value of ready-to-eat friariello campano (Brassica rapa L. subsp. sylvestris). J. Sci. Food Agric. 2009, 89, $2261-2266$. [CrossRef]

141. Dubuis, P.H.; Marazzi, C.; Städler, E.; Mauch, F. Sulphur deficiency causes a reduction in antimicrobial potential and leads to increased disease susceptibility of oilseed rape. J. Phytopathol. 2005, 153, 27-36. [CrossRef]

142. Kopsell, D.A.; Kopsell, D.E.; Curran-Celentano, J. Carotenoid pigments in kale are influenced by nitrogen concentration and form. J. Sci. Food Agric. 2007, 87, 900-907. [CrossRef]

143. Zhao, F.; Evans, E.J.; Bilsborrow, P.E.; Syers, J.K. Influence of nitrogen and sulphur on the glucosinolate profile of rapeseed (Brassica napus). J. Sci. Food Agric. 1994, 64, 295-304. [CrossRef]

144. Robbins, R.J.; Keck, A.S.; Banuelos, G.; Finley, J.W. Cultivation conditions and selenium fertilization alter the phenolic profile; glucosinolate; and sulforaphane content of broccoli. J. Med. Food 2005, 8, 204-214. [CrossRef] [PubMed]

145. Fabek, S.; Toth, N.; Redovnikovic, I.R.; Custic, M.H.; Benko, B.; Žutic, I. The effect of nitrogen fertilization on nitrate accumulation; and the content of minerals and glucosinolates in broccoli cultivars. Food Technol. Biotechnol. 2012, $50,9$.

146. Tolrà, R.P.; Poschenrieder, C.; Alonso, R.; Barceló, D.; Barceló, J. Influence of zinc hyperaccumulation on glucosinolates in Thlaspi caerulescens. New Phytol. 2001, 151, 621-626. [CrossRef]

147. Aghajanzadeh, T.A.; Prajapati, D.H.; Burow, M. Copper toxicity affects indolic glucosinolates and gene expression of key enzymes for their biosynthesis in Chinese cabbage. Arch. Agron. Soil Sci. 2020, 66, 1288-1301. [CrossRef]

148. Pandey, C.; Augustine, R.; Panthri, M.; Zia, I.; Bisht, N.C.; Gupta, M. Arsenic affects the production of glucosinolate, thiol and phytochemical compounds: A comparison of two Brassica cultivars. Plant Physiol. Biochem. 2017, 111, 144-154. [CrossRef] [PubMed]

149. Bodnaryk, R.P. Potent effect of jasmonates on indole glucosinolates in oilseed rape and mustard. Phytochemistry 1994, 35, 301-305. [CrossRef]

150. Mollers, C.; Nehlin, L.; Glimelius, K.; Iqbal, M.C.M. Influence of in vitro culture conditions on glucosinolate composition of microspore-derived embryos of Brassica napus. Physiol. Plant. 1999, 107, 441-446. [CrossRef]

151. Guo, R.; Shen, W.; Qian, H.; Zhang, M.; Liu, L.; Wang, Q. Jasmonic acid and glucose synergistically modulate the accumulation of glucosinolates in Arabidopsis thaliana. J. Exp. Bot. 2013, 64, 5707-5719. [CrossRef]

152. Gallo, M.; Esposito, G.; Ferracane, R.; Vinale, F.; Naviglio, D. Beneficial effects of Trichoderma genus microbes on qualitative parameters of Brassica rapa L. subsp. sylvestris L. Janch. Var. esculenta Hort. Eur. Food Res. Technol. 2013, 236, $1063-1071$. [CrossRef]

153. Muelchen, A.M.; Rand, R.E.; Parke, J.L. Evaluation of crucifer manures for controlling aphanomyces root rot of peas. Plant Dis. 1990, 74, 651-654. [CrossRef]

154. Pant, A.P.; Radovich, T.J.K.; Hue, N.V.; Talcott, S.T.; Krenek, K.A. Vermicompost extracts influence growth; mineral nutrients; phytonutrients and antioxidant activity in pak choi (Brassica rapa cv. bonsai; Chinensis group) grown under vermicompost and chemical fertiliser. J. Sci. Food Agric. 2009, 89, 2383-2392. [CrossRef]

155. Lola-Luz, T.; Hennequart, F.; Gaffney, M. Enhancement of phenolic and flavonoid compounds in cabbage (Brassica oleraceae) following application of commercial seaweed extracts of the brown seaweed; (Ascophyllum nodosum). J. Agric. Food Sci. 2013, 22, 288-295. [CrossRef]

156. Argento, S.; Raccuia, S.A.; Melilli, M.G.; Toscano, V.; Branca, F. Brassicas and their glucosinolate content for the biological control of root-knot nematodes in protected cultivation. Acta Hortic. 2013, 1005, 539-544. [CrossRef] 